\title{
DYNAMIC SYSTEMS APPROACH TO ASSESS AND MANAGE WATER RESOURCES IN RIVER BASINS
}

\author{
Rodrigo Máximo Sánchez-Román; Marcos Vinicius Folegatti²*; Alba María Guadalupe \\ Orellana González ${ }^{3}$; Rogério Teixeira da Silva ${ }^{1}$ \\ ${ }^{1}$ USP/ESALQ - Programa de Pós-Graduação em Irrigação e Drenagem. \\ ${ }^{2}$ USP/ESALQ - Depto. de Engenharia Rural, C.P. 9 - 13418-900 - Piracicaba, SP - Brasil. \\ ${ }^{3}$ USP/ESALQ - Programa de Pós-Graduação em Ecologia Aplicada-Interunidades. \\ *Corresponding author <mvfolega@esalq.usp.br>
}

\begin{abstract}
The Piracicaba, Capivari and Jundiaí River Basins (RB-PCJ) are located in the States of Minas Gerais and São Paulo, Brazil. By 2005, 5.8\% of Brazil’s General National Product-GNP was produced there. Such economic development has created a huge demand for water resources. The availability of water resources was assessed by running a dynamic systems simulation model to manage these resources in the RB-PCJ (WRM-PCJ), considering five 50-year simulations. WRM-PCJ was developed as a tool to aid the RB-PCJ Watershed Committee. The model computes water supply, demands, and contamination load from several consumers. When considering a Business-as-Usual scenario, by 2054 , water demands will have increased up to $76 \%, 39 \%$ of the available water will come from wastewater reuse, and the contamination load will have increased by $91 \%$. The Falkenmark Index started at $1403 \mathrm{~m}^{3}$ person ${ }^{-1}$ year $^{-1}$ in 2004, ending at $734 \mathrm{~m}^{3} \mathrm{P}^{-1} \mathrm{yr}^{-1}$ in 2054; the Xu Sustainability Index started at 0.44 and ended at 0.20; and Keller's River Basin Development Phases started as Phase II, and ended at final Phase III, of Augmentation. The three criteria used to evaluate water resources showed that RB-PCJ is at a crucial management turning point. The WRM-PCJ performed well, and proved to be an excellent tool to assess water resources availability.

Key words: water stress, water management, watershed, modeling
\end{abstract}

\section{APROXIMAÇÃO USANDO DINÂMICADE SISTEMAS PARA ESTIMAR E MANEJAR OS RECURSOS HÍDRICOS EM BACIAS HIDROGRÁFICAS}

\begin{abstract}
RESUMO: As Bacias Hidrográficas dos Rios Piracicaba, Capivari e Jundiaí (BH-PCJ) estão localizadas, nos Estados de Minas Gerais e São Paulo, Brasil. Em 2005 produziu 5.8\% do PIB brasileiro. Este desenvolvimento econômico demanda grandes volumes de água. Com o Modelo para a Gestão dos Recursos Hídricos das BH-PCJ (MRH-PCJ), desenvolvido em dinâmica de sistemas, cinco cenários para 50 anos foram simulados. O MRH-PCJ foi desenvolvido para ser uma ferramenta de gestão do Comitê de Bacia Hidrográfica. O modelo estima a oferta e demandas de água, e a carga contaminante dos diversos consumidores. No cenário Business as Usual, para 2054, as demandas de água incrementaram em 76\%, 39\% da água disponível terá origem em águas de reuso, e a carga contaminante incrementará 91\%. O Índice de Falkenmark, que em 2004 era de $1403 \mathrm{~m}^{3}$ pessoa ${ }^{-1}$ ano $^{-1}$, será $734 \mathrm{~m}^{3} \mathrm{P}^{-1}$ $a^{-1}$ em 2054; o Índice de Sustentabilidade de Xu iniciou em 0.44 e chegou até 0.20 ; quando consideradas as Fases de Desenvolvimento das Bacias Hidrográficas, propostas por Keller, iniciouse na Fase II, e terminou-se na Fase III, de Aumento. Os três critérios utilizados para avaliar os recursos hídricos mostraram que as BH-PCJ encontram-se num ponto de tomada de decisões importante. O MRH-PCJ mostrou-se uma excelente ferramenta para avaliar a disponibilidade de recursos hídricos. Palavras-chave: estresse hídrico, manejo de água, bacia hidrográfica, modelagem
\end{abstract}

\section{INTRODUCTION}

There are many perspectives, interests, perceptions, and alternatives for the use of water resources due to the diversity, positions, incomes, priorities, and locations of the people involved. However, the management of water resources should be associated with environ- mental sustainability, as a function of the growth of each component in the watershed. Growth of the population income implies in growth of water and food demand, but also in the contamination of water bodies (Falkenmark \& Molden, 2008). Water resources and the systemic approach have a direct relationship because both are systemic and non-linear (Ohlsson \& 
Turton, 1999). The basic principle of any systemic study is connectivity. A system is a set of elements with connections between each other. Any system is composed of subsystems, each being autonomous and open, directly interrelated and integrated with its environment (Santos, 1982).

The systemic approach is used in water resources management to analyze and improve water resources systems knowing that they are part of a dynamic and complex system, where many activities and exploitations coexist and interact. Each of these will require inputs (labor, power, capital etc.), and will produce outputs (agricultural and industrial goods and contaminants, residues etc.) (Costa, 1993).

Three watersheds form the Piracicaba, Capivari and Jundaí river basins (RB-PCJ), supplying water to $9 \%$ of Brazil's population in $0.18 \%$ of the Brazilian territory, producing 5.8\% of Brazil's General National Product-GNP (IBGE, 2007). Water supply and demand, sustainability and environmental contamination are important issues to be studied here. However, water resources sustainability should be linked to the users' capacity to conserve or increase life quality, maintaining and ensuring the resources for future generations (Turton, 1999). Ergo: Until when is it possible to maintain the productive activities, and satisfy population's growing demands without harming the sustainability of water resources? At what level of river basin development is the RB-PCJ?

\section{MATERIALAND METHODS}

\section{Characterization of the Study Area}

Three watersheds form the RB-PCJ system, referred to as Water Resources Management Unit 5 (UGRHI-5), covering 64 municipal districts: 60 belonging to the State of São Paulo and four to the State of Minas Gerais (PERH, 2005). The RB-PCJ has a total area of $15,414 \mathrm{~km}^{2}$.

The three rivers (Figure 1) flow toward the Tietê River and belong to the Tietê River Basin. The estimated population at UGRHI-5 in 2004 was 4434937 inhabitants in the urban area and 223998 inhabitants in the rural area (PERH, 2005). The main economic activities include manufacturing, agriculture, agro-industry, mining, recreation and landscaping, trading and services.

\section{Evolution of Water Resources Management in the Piracicaba, Capivari and Jundiaí Watersheds}

The state of São Paulo had been involved restructuring the water resources system since 1983. In 1986 the discussion began on the usefulness of looking at water resources from multiple aspects, causing an institutional and technical debate. The debate thus began to develop, and the resulting participation made 1987 a landmark year in the modernization of the water resources sector, as examples: Carta de Salvador (ABRH, 2008) and Decree No. 27576 (Comitê PCJ, 2008).

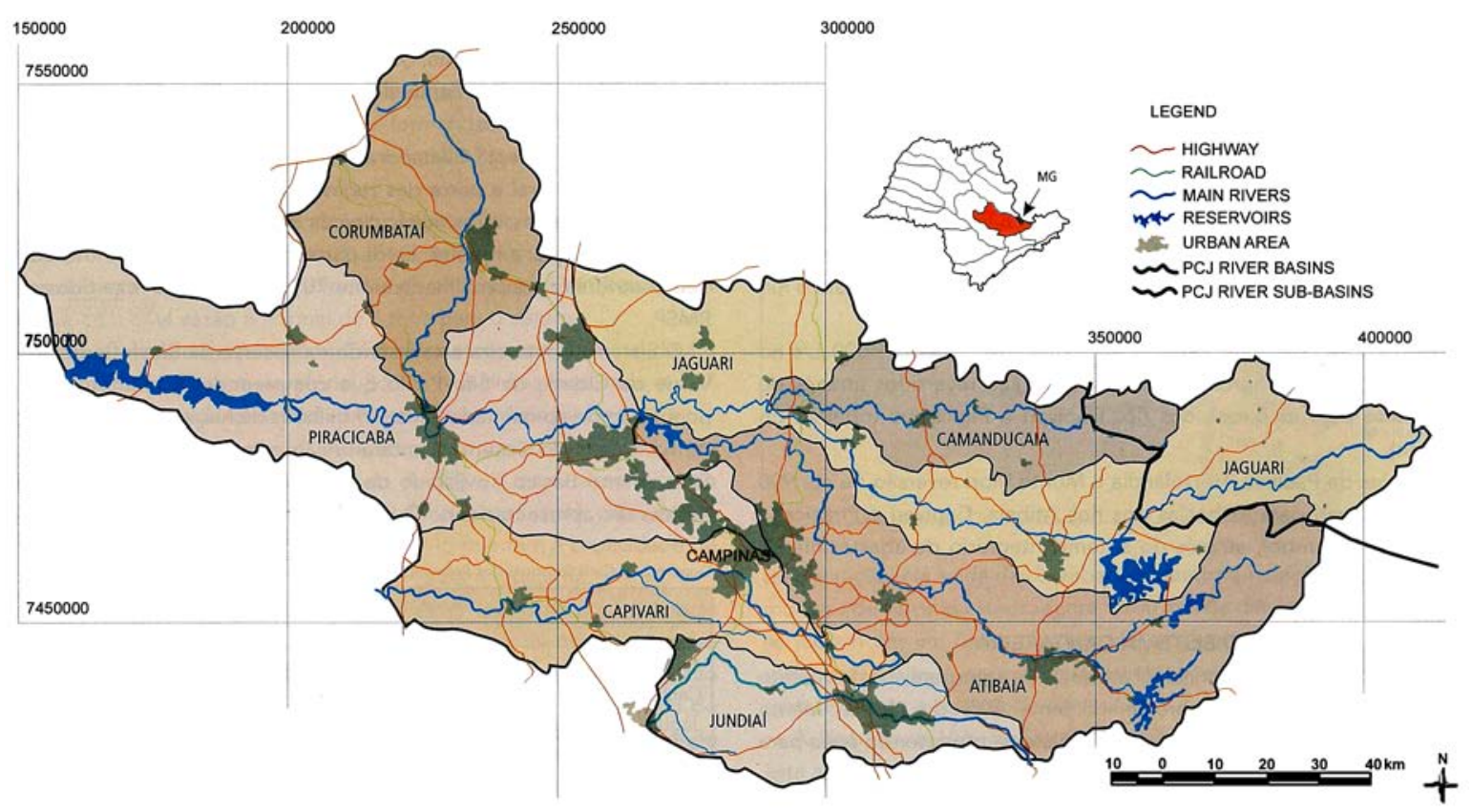

Figure 1 - Piracicaba, Capivari and Jundiaí River Basins (source: PBH, 2006). 
In 1989, in another pioneering initiative, several towns within the Piracicaba and Capivari river basins joined efforts to form the Inter-municipal Consortium of the Piracicaba and Capivari Watersheds, with the idea of encouraging, not only the environmental rehabilitation of the rivers, but establishing a regional integration and a development plan for the river basins. This initiative consolidated a new vision among local governments increasing the participation of the civil society in the water resources decision-making process. In 1993, the state of São Paulo established a collegial committee, Piracicaba, Capivari and Jundiaí River Basins Committees.

In 1997 Brazil faces the challenge of solving increasing water demands for urban, industrial and agricultural growth, potential conflicts generated by the supply versus demand status, and the advance of ecosystem degradation implementing Law 9433/97, which defines water as a good in the public domain, with its economic value, and priority uses for human and livestock consumption, and whose management is based on the watershed as a territorial unit. Its overall guideline is an integrated management, and the instruments they are to use in implementing the water resources plans, classifying bodies of water according to their main uses, the concession of water rights, water charges, public participation and the water resources information system. In this way, National Water Resources Policy was defined and the National Water Resources Management System created. In 2000, Law 9984 created the National Water Agency (ANA).

\section{Consumers' water demand}

Water demands were defined based on in situ studies of water consumption habits in the area. All information was collected and presented in several Water Resources State Plans, or came from many secondary information sources linked to agencies that support productive sectors, or from the water resources administration (DAEE, 2007; IBGE, 2007; IEA, 2007; INMET, 2007; INPE, 2007; IPEA, 2007; SIRGH, 2007; SAA-SP, 2007; PERH, 2005; UNICA, 2007).

In order to be effective and precise when modeling irrigated agriculture and animal breeding, it is necessary to have a detailed knowledge of water use consumption and wastewater generation. To accomplish that, it is necessary to conduct a water user census, with detailed information on water habits. The lack of information on these topics creates some uncertainties during the simulations.

In relation to ecological flow, several methodologies were considered to define a value for the simulations. To be on the safe side, it was decided that the smallest value that could be computed would be used; this consideration was based on the fact that the ecological flow value should be a decision made at the Piracicaba, Capivari and Jundiaí River Basins Committee (RBC-PCJ). A French method for existing water systems uses a value equal to $1 / 40$ of the average daily flow (Souchon \& Keith, 2001). According to PERH (2005), the average daily flow for the RB-PCJ is 64 $\mathrm{m}^{3} \mathrm{~s}^{-1}$; therefore, the ecological flow used during the WRM-PCJ runs was $1.6 \mathrm{~m}^{3} \mathrm{~s}^{-1}$.

\section{Relationship Between Dynamic Systems and Wa- ter Resources}

The Dynamic Systems (DS) methodology is based on and derived from the Theory of Control developed by Forrester (1961). The fundamental principle of this methodology is that every dynamic behavior is a consequence of the system structure (Powersim, 1996). It is characterized by changes occurring along time.

DS simulation models are real-world abstract descriptions. They allow the modeler to represent complex problems characterized by its dynamics, non-linearity, feedback relationships, and discrepancies in time and space (Wiazowski et al., 1999). A DS model should capture only the essential factors of a real system, disregarding all other factors. The main use of the models is to communicate a point of view of the world on specific problems; they do not try to be the reality, but to be as close as possible to it, and predict its behavior (Pérez Maqueo et al., 2006). The user should always be conscious of the model limitations he/she is using.

When focusing on a problem, there are several ways by which simulation models can be used. The objectives that guided the dynamic systems simulation model to manage water resources at the RB-PCJ (WRM-PCJ) construction defined the structure. Considering this, and based on other countries' experiences and other watershed development trends, a DS simulation model was developed and run in order to define the RB-PCJ developmental stage to date, and assess the availability of water resources and agriculture sustainability for the next 50 years.

WRM-PCJ uses DS on an object oriented simulation environment, the STELLA 9.0 (Iseesystems Co., Lebanon, NH, USA) platform. The model relates environmental, physical, social and economic elements to explain the dynamic behavior of water resources supply and demand, and wastewater generation by several existing consumers in the RB-PCJ. Simonovic \& Fahmy (1999) also integrated object-oriented system dynamics modeling approach to conduct a long-term water resource planning and policy analysis for the Nile River basin. The WRM-PCJ is a tool to aid policy and decision makers to seek out for different alternatives to manage water resources at RB-PCJ. 
To analyze the sustainability impact of water resources due to water supply and demand, WRM-PCJ uses: the Sustainability Index (Xu et al., 2002), which defines the relationship between total consumption and total available water; and the Falkenmark Index (Falkenmark, 1989; Falkenmark et al., 2007) which relates use-to-availability (Level of exploitation) and the number of people that have to share a unit of water (water shortage).

\section{Water Resources Systems Structures}

Figure 2 is the causal diagram for the water resources system structure that was modeled to analyze the water resources sustainability in the study area, the RB-PCJ. The Water Supply variables are: surface water and groundwater; both variables warrant the Water Stock from where water is drawn by consumers. Water Demand is the sum of all water demands from the population, environment, agro-industry, animal breeding, manufacturing, and agriculture.

\section{Water Resources Model for the Piracicaba, Capivari and Jundiaí River Basins (WRM-PCJ)}

WRM-PCJ is an explicit dynamic simulation model developed to simulate the RB-PCJ water resource system. The WRM-PCJ has 254 variables in 11 sectors; these sectors can be grouped into: demand, supply, and specific computations. The demand sectors are: Agriculture, Animal Breeding, Agro-industry, Environment, Population, and Manufacturing. The Supply Sector provides surface water and groundwater as a product of annual precipitation; precipitation is thus a variable that can change annually. The Computation Sector comprises: Volume of Returned Wastewater, Total Water Demand, Water Allocation Incomes, and Equivalent Population.

The water balance equation (1) and the total demand equation (2) for the RB-PCJ, expressed as differential equations in WRM-PCJ are:

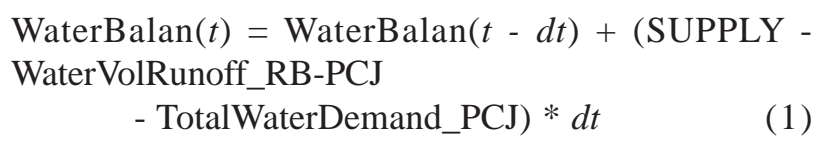$$
\text { - TotalWaterDemand_PCJ) } * d t
$$

$$
\begin{array}{r}
\text { TotalWaterDemand_PCJ }=\text { VTRAG + VTRAI + } \\
\text { VTRamb + VTRInd + VTRpop + VTRPEC + } \\
\text { (RMSP_Demand * } 86400 * 365)
\end{array}
$$

where: WaterBalan $(t)$ : Water balance for year $t\left(\mathrm{~m}^{3}\right.$ year $\left.{ }^{-1}\right)$; SUPPLY: Water Supply for year $t\left(\mathrm{~m}^{3}\right.$ year $\left.^{-1}\right)$; WaterVolRunoff_RB-PCJ: Water Volume that runs off the Piracicaba, Capivari and Jundiaí Watershed Ba$\sin \left(\mathrm{m}^{3}\right.$ year $\left.^{-1}\right)$; TotalWaterDemand_PCJ: Total Water Demand by consumers at the Piracicaba, Capivari and Jundiaí Watershed Basin $\left(\mathrm{m}^{3}\right.$ year $\left.^{-1}\right)$; VTRAG: Total Water Volume demanded by the agriculture sector $\left(\mathrm{m}^{3}\right.$ year $^{-1}$ ); VTRAI: Total Water Volume demanded by the agro-industry sector $\left(\mathrm{m}^{3}\right.$ year $\left.{ }^{-1}\right)$; VTRamb: Total Water Volume demanded as ecological flow $\left(\mathrm{m}^{3}\right.$ year $\left.^{-1}\right)$; VTRInd: Total Water Volume demanded by the manufacturing sector $\left(\mathrm{m}^{3}\right.$ year $\left.^{-1}\right)$; VTRpop: Total Water Volume demanded by the rural and urban population $\left(\mathrm{m}^{3}\right.$ year $\left.^{-1}\right)$; VTRPEC: Total Water Volume demanded by the animal breeding sector $\left(\mathrm{m}^{3}\right.$ year $\left.{ }^{-1}\right)$; RMSP_Demand: Total Water Volume diverted to supply water to the São Paulo Metropolitan Area $\left(\mathrm{m}^{3}\right.$ year $^{-1}$ ).

Figure 3 represents the structure of the water resources system linked to the Agriculture Sector in the study area as proposed in WRM-PCJ. The variable representing irrigation is $\operatorname{HMR}_{x i}\left(\mathrm{~L} \mathrm{~s}^{-1} \mathrm{ha}^{-1}\right)$, the irrigated areas are $\operatorname{Area}_{x i}$ (ha), and Total Volume Demanded by Agriculture is VTRAG $\left(\mathrm{m}^{3}\right.$ year $\left.^{-1}\right)$; $i$ represents the year and $x$ the annual value for each crop. The required water volume takes into consideration the crop's net demand plus irrigation system inefficiencies. Agriculture was modeled in five groups, representing a total of 60 different irrigated crops grown in the RB-PCJ.

Figure 4 represents the water resources supply structure linked to the Water Supply Section in the study area as proposed in WRM-PCJ.

The water supply variable is SUPPLY $\left(10^{6} \mathrm{~m}^{3}\right.$ year $^{-1}$ $=\mathrm{Mm}^{3}$ year $^{-1}$ ), representing precipitation volumes that became runoff volume (VolRunoff) or percolated and infiltrated volume annually (VolInf); additionally, return

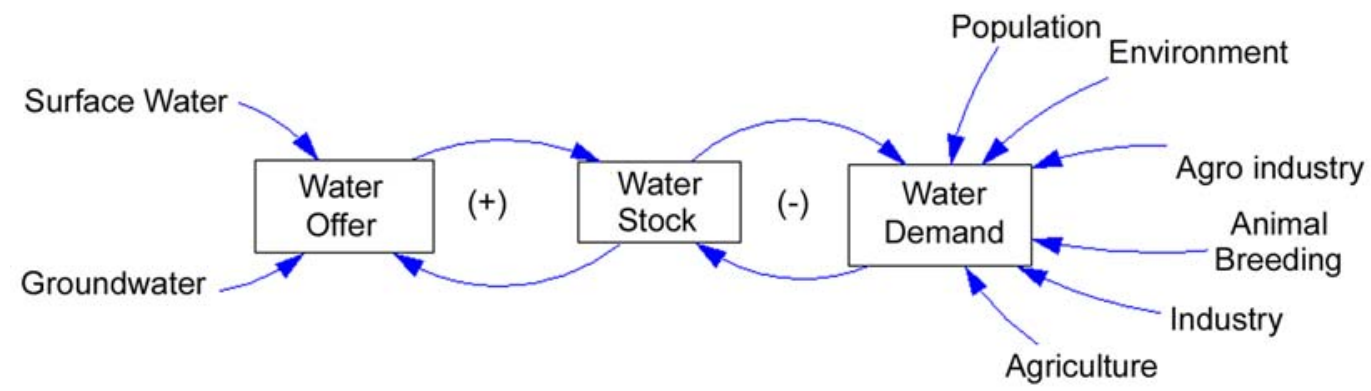

Figure 2 - Causal Diagram used for the Piracicaba, Capivari and Jundiaí Water Resources System. 


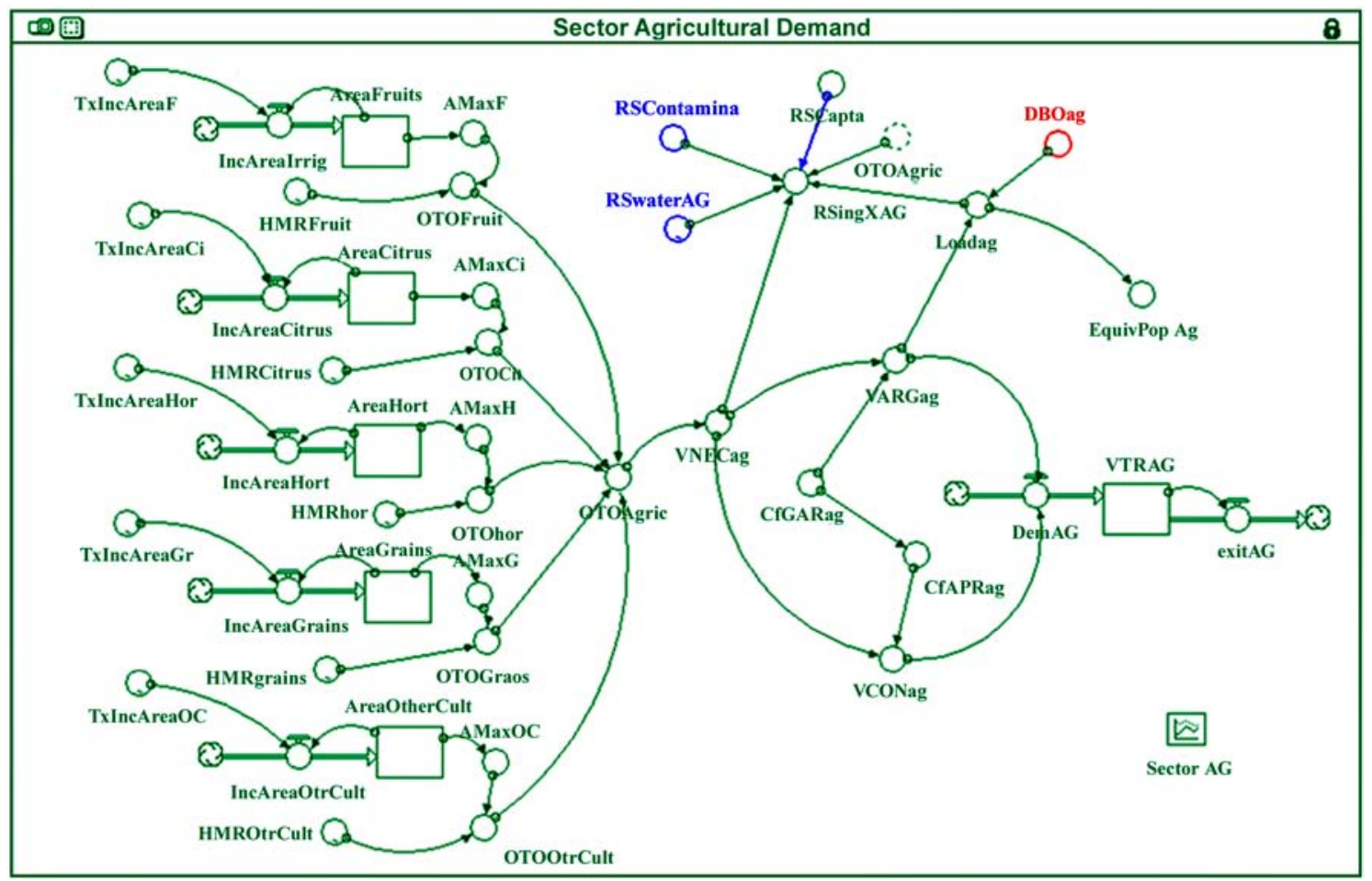

Figure 3 - Agricultural Sector represented by the Water Resources Model for the Piracicaba, Capivari and Jundiaí River Basins (WRMPCJ).

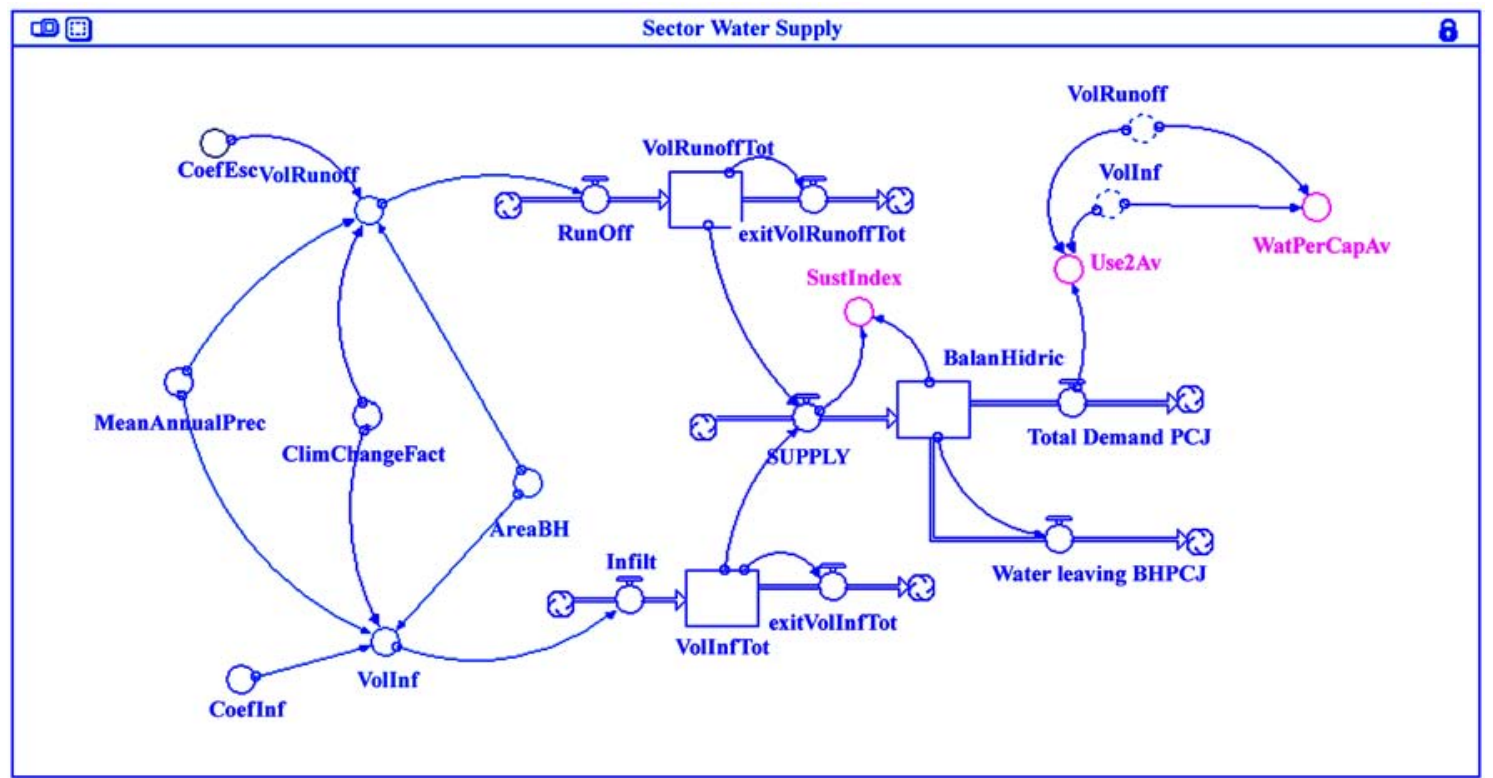

Figure 4 - Water Supply Sector represented by the Water Resources Model for the Piracicaba, Capivari and Jundiaí River Basins (WRMPCJ).

waters (VolARetorn) are also accounted as water supply. All these volumes are expressed as $\mathrm{Mm}^{3}$ year ${ }^{-1}$. The use-to-availability (Use2Av) parameter is also known as Water Resources Vulnerability Index by Raskin et al. (1997), and is used in the graphic proposed by Falkenmark et al. (2007) as the y axis in Figure 6.

\section{Simulation stage: application of the dynamics simulation model}

Five runs with a 50-year time frame were performed with a time step of one year. For Scenario 1, the consumption and wastewater generation rates of existing consumers at the RB-PCJ were maintained, with precipitations equal to the mean value, $1460 \mathrm{~mm}$ 
year $^{-1}$ (IRRIGART, 2004), throughout the simulation. Scenario 2 considers a $10 \%$ reduction in precipitation due to climatic changes, without variation in all other variables. Scenario 3 considers that the total irrigated area will stop growing by the year 2020, without variation in all other variables. Scenario 4 considers the same conditions as in scenario 1 except for ecological flow, which is here equal to $19.2 \mathrm{~m}^{3} \mathrm{~s}^{-1}$. Scenario 5 considers the conditions established in scenario 4 and changes in population water demand habits as shown in Figure 5 (Table 1). According to RB-PCJ Plan (PBH, 2006) urban water consumption in the RB-PCJ is around $400 \mathrm{~L}_{\text {person }}{ }^{-1}$ day $^{-1}$, while for EU countries urban water consumption is less than $270 \mathrm{~L}^{-1}$ person $^{-1}$ day $^{-1}$ (UNEP, 2007).

\section{RESULTS AND DISCUSSION}

For a 50-year simulation period (Table 2), considering a BaU scenario for the RB-PCJ, there was an $\approx 76 \%$ increase in total water demand. Under the $\mathrm{BaU}$ scenario, in 2004 the total demand represented $\approx 74 \%$ of the total available water volume without considering the reuse of waters; in 2007 it goes up to $\approx 82 \%$, and for 2024 it is expected that the RB-PCJ will become a closed basin for two years (Figure 6). Household water consumption changes were foreseen by PERH (2005), and would produce a change in water demand conditions for about six years in the basin; however, by 2032 the basin would be closed again, this time on a permanent basis. From this point for-

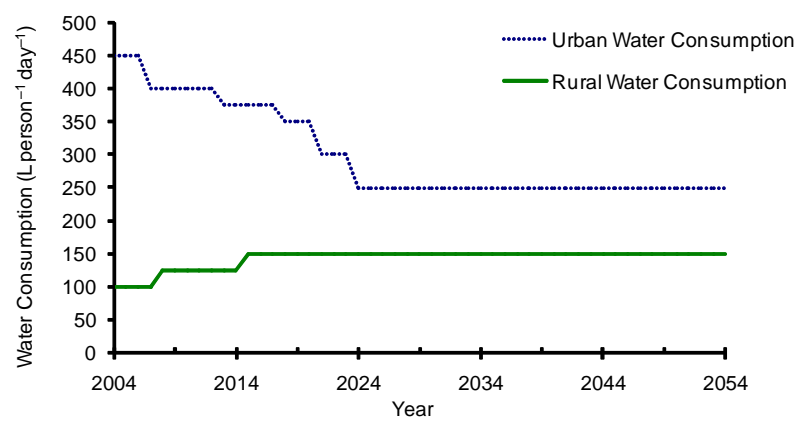

Figure 5 - Urban and Rural Water Consumption Demand considered for Scenario 5. ward, reused water will be the only available water source to supply new consumers. These waters will represent $\approx 39 \%$ of the available water by 2054 . The other four scenarios showed the same tendency toward a closed watershed situation before the end of the simulation time frame.

New wastewater treatment plant stations should be built, since it is expected that the total load will increase by up to $\approx 93 \%$ by 2054 when considering the $\mathrm{BaU}$ scenario. For this scenario in the 50 -year simulation time frame, water demands will increase up to $\approx 24 \%$ by 2030 when compared against demands in 2004 , and $\approx 31 \%$ of the available water volume will come from wastewater reuse, whereas $\approx 98 \%$ of all available water resources will be used. The total contamination load by 2030 was estimated to increase by up to $\approx 39 \%$. By 2054 , conditions will be more stressful considering that water demand will have increased by up to $\approx 76 \%$ when compared with 2004 ; $\approx 39 \%$ of the available water volume will come from wastewater reuse. The total water resources demand will rise by up to $\approx 131 \%$ of the available volume. Meanwhile, the contamination load will have increased by up to $\approx 91 \%$ when compared with 2004 .

Wastewater reuse will increase water supply, but the water volume required to ensure water dilution and

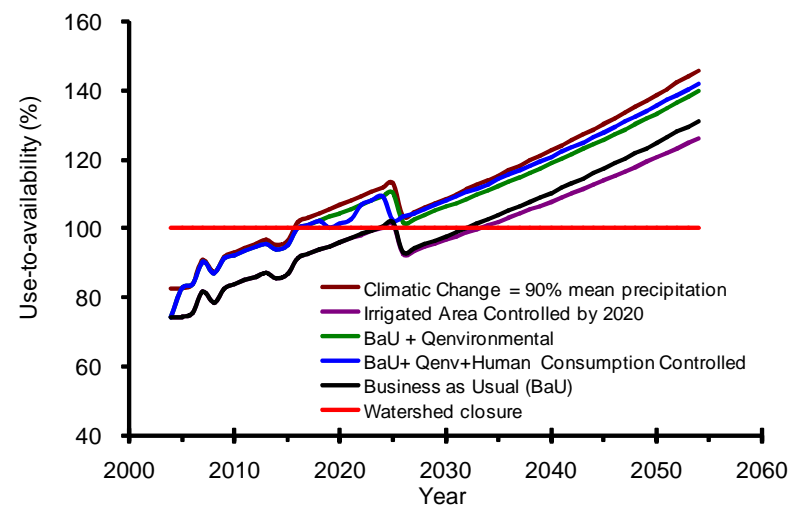

Figure 6 - Use-to-availability for the Piracicaba, Capivari and Jundiaí River Basins estimated using the Water Resources Model (WRM-PCJ) for the Piracicaba, Capivari and Jundiaí River Basins under five scenarios and a 50-year time frame simulation.

Table 1 - Proposed and evaluated scenarios using the Water Resources Model for the Piracicaba, Capivari, and Jundiaí River Basins (WRM-PCJ) in a 50-year time frame.

\begin{tabular}{lll}
\hline Scenario & Class & Description \\
\hline 1 & BaU & Business-as-Usual \\
2 & Climatic change & Water offer reduced by $10 \%$ \\
3 & Limited irrigated area & Agricultural irrigated area stops growing by 2020 \\
4 & BaU + Qenv. $=19.2 \mathrm{~m}^{3} \mathrm{~s}^{-1}$ & BaU + Environmental flow as 30\% of mean river flow \\
5 & Integrated scenario & Combine Scenario 4 \& Human Water Consumption Controlled \\
\hline
\end{tabular}


Table 2 - Supply, Total Demand and Balance simulated using the Water Resources Model for the Piracicaba, Capivari and Jundiaí River Basins (WRM-PCJ) in a 50-year time frame under the $\mathrm{BaU}$ scenario.

\begin{tabular}{lccc}
\hline Year & Supply & Total Demand & Balance \\
\hline & $-\cdots-1$ & & \\
\hline 2004 & 8734 & 4865 & 3869 \\
2007 & 8900 & 5350 & 3551 \\
2010 & 9182 & 5488 & 3693 \\
2020 & 9653 & 6279 & 3375 \\
2030 & 9563 & 6394 & 3169 \\
2040 & 10017 & 7216 & 2801 \\
2050 & 10539 & 8164 & 2375 \\
2054 & 10769 & 8583 & 2186 \\
\hline
\end{tabular}

the sustainability of water body ecosystems will be under great stress, since more wastewater reuse will become a water source for human activities. Without any doubt, this situation will increase water treatment prices, and foreseen alternatives to solve this situation are a must.

River basin water resources develop through a sequence, conceptualizing the development phases that all river basins will tend to pursue. This tendency, according to Keller et al. (1998), follows a general progression through three development phases (each with two sub-phases): Exploitation ( $<60 \%$ of the ratio Use/ Net Withdraws - U/NW), Conservation $(<90 \%$ U/NW) and Augmentation ( $>90 \% \mathrm{U} / \mathrm{NW})$. As basins progress throughout development phases, they would approach closure.

Table 3 - Relationship between Water shortage and Level of exploitation estimated using the Water Resources Model for the Piracicaba, Capivari and Jundiaí River Basins in a 50-year time frame simulation under five scenarios.

\begin{tabular}{|c|c|c|c|c|c|}
\hline \multirow[b]{2}{*}{$\begin{array}{l}\text { Water shortage } \\
\left(\text { Person } \mathrm{m}^{-3} \text { year }{ }^{-1}\right)\end{array}$} & \multicolumn{5}{|c|}{ Scenarios' Level of exploitation (\%) } \\
\hline & $\begin{array}{c}\text { Business as Usual } \\
(\mathrm{BaU})\end{array}$ & $\begin{array}{c}\text { Climatic change }= \\
90 \% \text { Mean } \\
\text { Precipitation }\end{array}$ & $\begin{array}{c}\text { Irrigated area } \\
\text { controlled at } \\
2020 \\
\end{array}$ & $\begin{array}{c}\mathrm{BaU}+\text { Qenv }= \\
19.2 \mathrm{~m}^{3} \mathrm{~s}^{-1}\end{array}$ & $\begin{array}{l}\text { BaU + Qenv }=19.2 \mathrm{~m}^{3} \mathrm{~s}^{-1} \\
+ \text { Household Consumption } \\
\text { Controlled }\end{array}$ \\
\hline 700 & $75.19^{\dagger}$ & $74.19^{\dagger}$ & $75.99^{\dagger}$ & $80.91^{\dagger}$ & $80.05^{\dagger}$ \\
\hline 800 & 85.85 & 86.04 & 85.61 & 92.3 & 92.1 \\
\hline 900 & 95.25 & 96.48 & 94.1 & 102.35 & 102.73 \\
\hline 1000 & 103.66 & 105.83 & 101.69 & 111.34 & 112.23 \\
\hline 1100 & 111.27 & 114.28 & 108.56 & 119.47 & 120.83 \\
\hline 1200 & 118.22 & 122 & 114.83 & 126.89 & 128.68 \\
\hline 1300 & 124.6 & & 120.59 & 133.72 & 135.9 \\
\hline 1400 & $130.52^{\ddagger}$ & 134.67 & $125.93^{\ddagger}$ & $140.05^{\ddagger}$ & $142.59^{\ddagger}$ \\
\hline \multicolumn{6}{|l|}{1500} \\
\hline 1600 & & $147.52^{\ddagger}$ & & & \\
\hline
\end{tabular}

Note: ${ }^{\dagger}$ Values for year 2004; ${ }^{\ddagger}$ Values for year 2054.

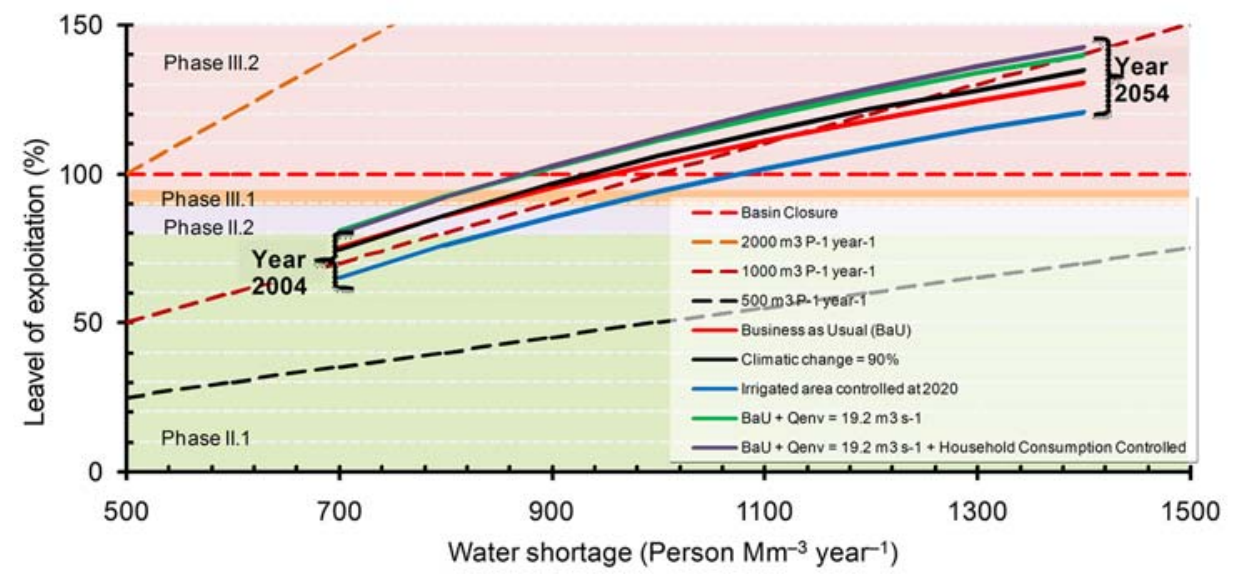

Figure 7 - Relationship between Total Water Demand and Water Availability, in percentage (vertical axis), and Population Density per Unit of Flow (horizontal scale) estimated using the Water Resources Model for the Piracicaba, Capivari and Jundiaí River Basins (Adapted from: Falkenmark et al., 2007; and Keller et al., 1998) in a 50-year time frame simulation under five scenarios. 
When basin development was analyzed using Keller et al. (1998), it was noticed that in 2007 the RB-PCH was at Phase II, stage 1: Conservation Phase (Figure 7). During this stage of development policies to reduce water demand and to increase water use efficiency should be taken. Under the BaU scenario, by 2008 the RB-PCJ will be entering Phase II, stage 2, the final stage of this phase. By 2016 the RB-PCJ will be at the initial stage of Phase III, the Augmentation Phase. This is the final basin development phase, when water resources will have to come from water transfers or by desalting water. In this particular regard, the other scenario predictions are also not very encouraging.

The Falkenmark Index for the year 2004 (Figure 7 and Table 3) under the BaU scenario started at 1403 $\mathrm{m}^{3}$ inhabitant ${ }^{-1}$ year $^{-1}$ (713 inhab $\mathrm{Mm}^{-3}$ year ${ }^{-1}$ ) in the RB-PCJ; by 2030 it will have gone down to $1008 \mathrm{~m}^{3}$ inhab $^{-1}$ year $^{-1}$ (992 inhab $\mathrm{Mm}^{-3}$ year $^{-1}$ ); and by 2054 it will end up at $734 \mathrm{~m}^{3}$ inhab ${ }^{-1}$ year $^{-1}$ (1363 inhab $\mathrm{Mm}^{-3}$ year $\left.^{-1}\right)$. Water stress exists when values are between 1000 and $1600 \mathrm{~m}^{3}$ inhab $^{-1}$ year $^{-1}$, and chronic water shortage occurs when water available volume is between 500 and $1000 \mathrm{~m}^{3}$ inhab $^{-1}$ year $^{-1}$; for values smaller than $500 \mathrm{~m}^{3}$ inhab $^{-1}$ year $^{-1}$, water resources are beyond the management capacity barrier (Falkenmark, 1989). Table 3 confirms the watershed's tendency towards basin closure.

The watershed's predisposition is confirmed (Table 4) as a highly populated watershed that contains a very important industrial sector in Brazil, inspite of the scenario considered. Regardless of the analyzed scenario the main consumers in the RB-PCJ are Population and Manufacturing. During the modeling and simulation process it was noticed that urban household water consumption at the RB-PCJ is high when compared with other countries, even developing countries such as those that belong to the European Union (EU). Poli- cies toward the management of water resources should take into consideration these two sectors to be really effective to ensure water resources sustainability.

The Sustainability Index (SI) as proposed by $\mathrm{Xu}$ et al. (2002) (Figure 8) and estimated using WRM-PCJ shows that under the BaU scenario, by 2004 the SI is 0.44 ; it will have decreased to 0.33 by 2030 , and to 0.20 by 2054 . The WRM-PCJ considers wastewater reuse as part of available water when SI is computed, in contrast with the result presented by the use-toavailability relation on the y-axis in Figure 6. If the SI value is greater than 0.2 , then there is low or no stress with regard to water supply; if the SI value is smaller than 0.2 then the water resources are vulnerable. SI values equal to zero indicates that the water supply is unsustainable.

The various methods to assess water resources and basin development at the RB-PCJ show that appropriate and urgent decisions should be made to stop the deterioration of the available water resources. By 2030 the RB-PCJ water resources situation will be extremely demanding and stressful, as shown by the estimated

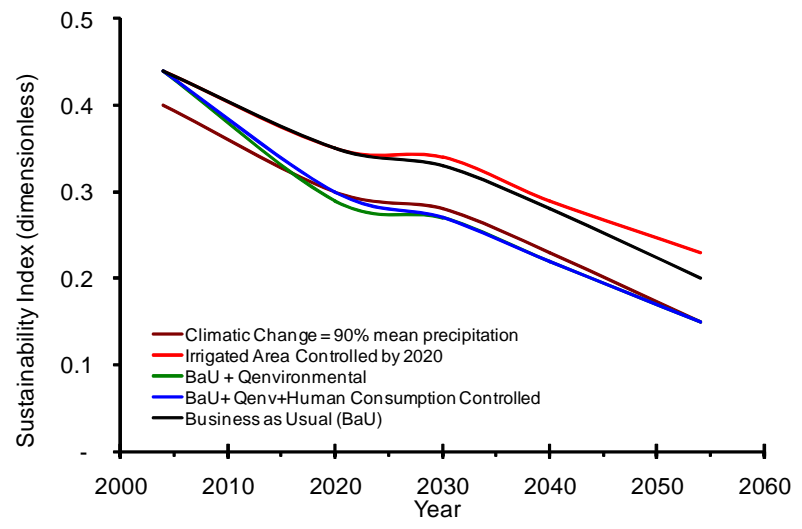

Figure 8 - Sustainability Index, proposed by Xu et al. (2002), estimated using the Water Resources Model for the Piracicaba, Capivari and Jundiaí River Basins (WRMPCJ).

Table 4 - Water Consumption by Sector, in percentage, computed for five scenarios using the Water Resources Model for the Piracicaba, Capivari and Jundiaí River Basins from 2004 to 2054.

\begin{tabular}{|c|c|c|c|c|c|c|}
\hline \multirow[b]{2}{*}{$\begin{array}{l}\text { Simulated Sectors } \\
\text { by WRM-PCJ }\end{array}$} & \multirow[b]{2}{*}{$\begin{array}{c}\text { Initial values } \\
\text { (year 2004) }\end{array}$} & \multicolumn{5}{|c|}{ Estimated values, by scenario, for year 2054} \\
\hline & & $\begin{array}{l}\text { Business as } \\
\text { Usual (BaU) }\end{array}$ & $\begin{array}{l}\text { Climatic change } \\
=90 \% \text { Mean } \\
\text { Precipitation }\end{array}$ & $\begin{array}{c}\text { Irrigated Area } \\
\text { Controlled at } \\
2020 \\
\end{array}$ & $\begin{array}{c}\quad \mathrm{BaU}+ \\
\text { Qenviromental } \\
=19.2 \mathrm{~m}^{3} \mathrm{~s}^{-1}\end{array}$ & $\begin{array}{c}\mathrm{BaU}+\text { Qenv }=19.2 \mathrm{~m}^{3} \\
\mathrm{~s}^{-1}+\text { Population Water } \\
\text { Demand Controlled }\end{array}$ \\
\hline & & & -...-. Water & consumption $(\%$ & $-\cdots-1-1$ & - \\
\hline Population & 53.75 & 50.07 & 50.07 & 52.33 & 46.67 & 47.68 \\
\hline Industry & 31.20 & 34.20 & 34.20 & 35.74 & 31.87 & 31.26 \\
\hline Environmental & 1.30 & 0.66 & 0.66 & 0.69 & 7.42 & 7.28 \\
\hline Agricultural Sector & 13.75 & 15.07 & 15.07 & 11.23 & 14.04 & 13.78 \\
\hline Irrigated Agriculture & 10.22 & 11.20 & 11.20 & 7.19 & 10.43 & 10.24 \\
\hline Agro-industry & 0.14 & 0.15 & 0.15 & 0.15 & 0.14 & 0.14 \\
\hline Animal Breeding & 3.39 & 3.72 & 3.72 & 3.89 & 3.47 & 3.40 \\
\hline
\end{tabular}


coefficients. Additionally, by 2054, the situation will be on the verge of becoming unsustainable. Therefore, appropriate steps must be taken now seeking a water resources management policy to avoid an ecological chaos in the RB-PCJ.

\section{CONCLUSIONS}

All scenarios also showed that the RB-PCJ will be at a chronic water shortage situation by 2054. The model and system dynamics methodology herein developed proved to be a useful tool to plan, analyze and assess water resources systems and policies towards water resources sustainability. WRM-PCJ could be of great importance to the local government, watershed conservation planners and watershed committee members to develop sustainable water resources management practices and policies considering state and regional development, environmental concerns and ecological needs at RB-PCJ.

\section{ACKNOWLEDGMENTS}

The authors thank CNPq (151864/2007-1), INCTEI and FAPESP (2006/60954-4) for financial support and scholarships awarded.

\section{REFERENCES}

ASSOCIAÇÃO BRASILEIRA DE RECURSOS HÍDRICOS - ABRH. Available at: http://www.abrh.org.br/cartasalvador.doc. Accessed 26 May 2008.

COMITÊ DAS BACIAS DOS RIOS PIRACICABA, CAPIVARI E JUNDIAÍ - COMITÊ CPJ. Available at: http:// www.comitepcj.sp.gov/download/Decreto-27576-87.pdf. Accessed 26 May 2008.

COSTA, M.P.B. Agroecologia: uma alternativa viável às áreas reformadas e à produção familiar. Revista Reforma Agrária, v.23, p.53-69, 1993.

DEPARTAMENTO DE ÁGUAS E ENERGIA ELÉTRICA - DAEE. Available at: http://www.daee.sp.gov.br/. Accessed 06 May 2007.

FALKENMARK, M.; MOLDEN, D. Wake up to realities of river basin closure. International Journal of Water Resources Development, v.24, p.201-215, 2008.

FALKENMARK, M.; BERNTELL, A.; JÄGERSKOG, A.; LUNDQVIST, J.; MATZ, M.; TROPP, $\mathrm{H}$. On the verge of a new scarcity: call goes good governance and human ingenuity; Stockholm: Stockholm International Water Institute, 2007. 20p.

FALKENMARK, M. The Massive water scarcity now threatening africa-why isn't it being addressed? Ambio, v.18, p.112-118, 1989.

FORRESTER, J.W. Industrial dynamics. Cambridge, M.I.T. Press, 1961. 464p.

INSTITUTO BRASILEIRO DE GEOGRAFIA E ESTATÍSTICA IBGE. Available at: http://www.ibge.gov.br/home/. Accessed 30 May 2007.

INSTITUTO DE ECONOMIA AGRÍCOLA - IEA. Available at: http://www.iea.sp.gov.br/. Accessed 14 May 2007.

INSTITUTO NACIONAL DE METEOROLOGIA - INMET. Available at: http://www.inmet.gov.br/. Accessed 12 May 2007.
INSTITUTO NACIONAL DE PESQUISAS ESPACIAIS - INPE. Available at: http://www.inpe.br/. Accessed 22 May 2007.

INSTITUTO DE PESQUISA ECONÔMICA APLICADA - IPEA. Available at: http://www.ipea.gov.br/. Accessed 28 May 2007.

IRRIGART. Relatório da situação dos recursos hídricos das bacias hidrográficas dos rios Piracicaba, Capivari e Jundiaí - 2002/2003. Piracicaba: Comitê das Bacias Hidrográficas dos Rios Piracicaba, Capivari e Jundiaí, 2004. 496p.

KELLER, J.; KELLER, A.; DAVIDS, G. River basin development phases and implications of closure. Journal of Applied Irrigation Science, v.33, p.145-163, 1998.

OHLSSON, L.; TURTON, A.R. The turning of screw: social resource scarcity the the bottle-neck in adaptation to water scarcity. London: University of London, 1999. 8p. (SOAS Occasional Paper, 19).

PÉREZ MAQUEO, O.; DELFÍN, C.; FREGOSO, A.; COTLER, H. Modelos de simulación para la elaboración y evaluación de los programas de servicios ambientales hídricos. Gaceta Ecológica, v.78, p.65-84, 2006.

$\mathrm{PBH}$. Plano de bacias hidrográficas 2004-2007 dos rios Piracicaba, Capivari e Jundiaí: síntese do relatorio final. São Carlos: SHS Consultoria e Projetos de Engenharia, 2006. 48p.

PERH. Plano Estadual dos Recursos Hídricos 2004-2007 do Estado de São Paulo:- relatório síntese do plano. Piracicaba: Consórcio JMR Engecorps, 2005. 47p.

POWERSIM. Introduction to system dynamics. Reston: Powersim Press, 1996. 44p.

RASKIN, P.; GLEICK, P.; KIRSHEN, P.; PONTIUS, G.; STRZEPEK, K. Water futures: assessment of long-range patterns and prospects. Stockholm: Stockholm Environment Institute, 1997. 77p.

SANTOS, M. O espaço e os seus elementos: questões de método. Revista Geografia e Ensino, v.1, p.19-30, 1982.

SECRETARIA DE AGRICULTURA E ABASTECIMENTO DO ESTADO DE SÃO PAULO.- SAA-SP Available at: http:// www.agricultura.sp.gov.br/. Accessed 03 May 2007.

SIRGH. Sistema de Informações para o Gerenciamento de Recursos Hídricos do Estado de São Paulo Available at: http:// www.sigrh.sp.gov.br/cgi-bin/bdhm.exe/plu . Accessed 25 Apr. 2007.

SIMONOVIC, S.P.; FAHMY, H. A new modeling approach for water resources policy analysis. Water Resources Research, v.35, p.295-304, 1999.

SOUCHON, Y.; KEITH, P. Freshwater fish habitat: science, management and conservation in France. Aquatic Ecosystem Health and Management Society, v.4, p.401-412, 2001.

TURTON, A.R. Water scarcity and social adaptive capacity: towards an understanding of the social dynamics of water demand management in developing countries. London: University of London, 1999, 23p. (SOAS Occasional Paper, 9).

UNIÃO DA INDÚSTRIA DE CANA-DE-AÇÚCAR - UNICA. Available at: http://www.portalunica.com.br. Accessed 12 May 2007.

UNITED NATIONS ENVIRONMENT PROGRAMME - UNEP. Freshwater in Europe, 2007. Available at: http:// www.grid.unep.ch/product/publication/freshwater_europe/ consumption.php. Acessed 28 Sept. 2007.

WIAZOWSKI, B.A.; SILVA, C.A.B; LOURENZANI, W.L. O uso de sistemas dinâmicos como ferramenta de aprendizagem. Economia Rural, v.3, p.29-33, 1999.

XU, Z.X.; TAKEUCHI, K.; ISHIDARA, H.; ZHANG, X.W. Sustainability analysis for Yellow River water resources using the system dynamics approach. Water Resources Management, v.16, p.239-261, 2002.

Received October 22, 2007

Accepted January 23, 2009 